\title{
Li-ion electrode nanocomposites with self-assembled conductive carbon layers*)
}

\author{
Marcin Molenda ${ }^{1) * *)}$, Joanna Świder ${ }^{1)}$, Michał Świętosławski ${ }^{11}$, Andrzej Kochanowski ${ }^{1)}$ \\ DOI: dx.doi.org/10.14314/polimery.2017.532
}

\begin{abstract}
Basing on the developed and patented technology the nanocomposite cathodes were successfully prepared in a simple and inexpensive process of wet impregnation of polymer carbon precursor followed by controlled pyrolysis. Conductive carbon layers (CCLs) derived from hydrophilic polymers in solvent-free water mediated process, significantly enhances electrical conductivity of the material and improves its thermal properties, moreover the unique pore structure of CCLs assures easy lithium ions diffusion. Proposed solution allows to explore the potential of active material and improves overall performance of Li-ion batteries.
\end{abstract}

Keywords: Li-ion batteries, nanocomposites, carbon coating, conductive carbon layers, hydrophilic polymers.

\section{Nanokompozyty elektrodowe Li-ion z samoorganizującymi się przewodzą- cymi warstwami węglowymi}

Streszczenie: Na podstawie opracowanej i opatentowanej technologii otrzymano nanokompozyty elektrodowe Li-ion. Nieskomplikowany i niedrogi proces wytwarzania przewodzących warstw węglowych (CCL) polegał na depozycji w środowisku wodnym prekursora węglowego na powierzchni ziaren materiału aktywnego, a następnie na kontrolowanej jego pirolizie. Otrzymane powłoki węglowe z hydrofilowych polimerów $\mathrm{w}$ istotnym stopniu polepszają właściwości elektryczne i termiczne kompozytów elektrodowych, a jednocześnie zapewniają kanały transportu (dyfuzji) jonów litu przez powłokę węglową. Zaproponowane rozwiązanie umożliwia pełne wykorzystanie korzystnych właściwości materiału aktywnego i poprawia ogólne parametry pracy ogniw litowo-jonowych.

Słowa kluczowe: akumulatory Li-ion, nanokompozyty, powłoki węglowe, przewodzące warstwy węglowe, polimery hydrofilowe.

Nowadays, most lithium-ion batteries (LIBs) are used in portable electronic devices (such as cell phones and laptops). The fast growing of global LIBs market is due to increasing demand across various energy storage sectors like automotive, military and industry. The market is currently driven by usage of LIBs in electric vehicles and hybrid electric vehicles (xEV). Li-ion technology will dominate in the applications mentioned above for, at least, next two decades. Moreover, the new application areas, such as stationary high power energy storage systems (ESS) for renewable energy (photovoltaic, wind energy) and smart grids will promote the further dynamic growth of LIBs market. Nevertheless, there are still needed im-

\footnotetext{
1) Jagiellonian University, Department of Chemical Technology, Faculty of Chemistry, Ingardena 3, 30-060 Cracow, Poland. *) This material was presented at $9^{\text {th }}$ International Conference MoDeSt 2016, 4-8 September 2016, Cracow, Poland.

**) Author for correspondence; e-mail: molendam@chemia. uj.edu.pl
}

provements in safety, durability and reliability, energy and power density together with cost reductions [1].

The technology of rechargeable lithium cells dates back to the early 70's of last century [2], when the first cell using lithium intercalation process in $\mathrm{Li} / \mathrm{Li}^{+} / \mathrm{Li}_{x} \mathrm{TiS}_{2}$ system was developed. Low working potential $(2 \mathrm{~V})$ and capacity of the cell as well as the application of metallic lithium as an anode which formed crystalline dendrites during cell charging did not allow the successful commercialization of the solution. The breakthrough in the technology of lithium batteries (1980's) was the concept of replacing metallic lithium with intercalation material - graphite [3-5]. The new technology, so called rocking chair and later Li-ion, required the development of cathode material with a higher potential towards lithium which was layered oxide $\mathrm{LiCoO}_{2}$ (LCO). The first, commercially available Li-ion battery of formula $\mathrm{Li}_{\mathrm{x}} \mathrm{C}_{6} / \mathrm{Li}^{+} / \mathrm{Li}_{1-\mathrm{C}} \mathrm{CoO}_{2}$, was introduced on the market by Sony Co. in 1991. Until the present day, most of commercial Li-ion batteries is based on LCO material or related systems such as $\mathrm{LiNi}_{\mathrm{y}} \mathrm{Co}_{1-\mathrm{y}} \mathrm{O}_{2^{\prime}} \mathrm{LiMn}_{\mathrm{y}} \mathrm{Co}_{1-\mathrm{y}} \mathrm{O}_{2^{\prime}}, \mathrm{LiMn}_{1 / 3} \mathrm{Ni}_{1 / 3} \mathrm{Co}_{1 / 3} \mathrm{O}_{2}(\mathrm{NMC})$, $\mathrm{Li}\left(\mathrm{Ni}_{0.85} \mathrm{Co}_{0.1} \mathrm{Al}_{0.05}\right) \mathrm{O}_{2}$ (NCA) [4, 6]. The batteries reveal re- 
versible capacity of $<180 \mathrm{mAh} / \mathrm{g}$ and working potential 3.6-3.7 V. Toxic behavior and high cost of cobalt compounds as well as their high reactivity towards electrolyte (risk of self-ignition of the cell - Thermal Runaway process) limit application in high-power batteries [4]. It is crucial to emphasize the aspects of the safety and stability of Li-ion batteries which result from the chemistry of materials and significantly affect economic outcomes of cell manufacturers (the costs of replacing defective cells and compensation for damages resulting from cells failure). The quest for new, safer and cheaper cathode materials resulted in proposition of new three-dimensional materials $-\mathrm{LiMn}_{2} \mathrm{O}_{4}(\mathrm{LMO})$ spinel $[4,5,7,8]$ and $\mathrm{LiMXO}_{4}(\mathrm{M}=\operatorname{metal} 3 d, \mathrm{X}=\mathrm{S}, \mathrm{P}, \mathrm{As}, \mathrm{Mo}, \mathrm{W})$ [9] systems, in particularly $\mathrm{LiFePO}_{4}(\mathrm{LFP})$.

$\mathrm{LiFePO}_{4}$ (LFP) material of orthorhombic olivine structure (Pnma) reveals theoretical capacity of $170 \mathrm{mAh} / \mathrm{g}$ and working potential $3.5 \mathrm{~V}$. It is a low cost material with high chemical and thermal stability resulting from strong covalent bonds of $\mathrm{PO}_{4}^{3-}$ tetrahedron in the structure. This improves cells safety and stability. LFP material reveals poor electrical conductivity $\left(\sim 10^{-9} \mathrm{~S} / \mathrm{cm}\right.$ at room temperature) and specific one-dimension paths (direction [010]) for lithium ions diffusion which limit practical application. To overcome the above limitations the grain size of LFP active material should be lowered, to shorten effectively the diffusion path, and covered by carbon layers (so called carbon nanopainting) - formation of C/LFP nanocomposites [10-13]. The developed methods of C/LFP nanocomposites preparation are mostly one-step processes, i.e., carbon coating is formed simultaneously with LFP active material under conditions being compromise resulting from the simultaneous preparation of both composite components. In result, there is no possibility to control morphology of LFP active material which affects electrochemical performance and the optimization of morphology and electrochemical properties of the carbon coatings is not possible as well. On the other hand, the methods of C/LFP nanocomposites preparation from carboxylic acids [14], polyalcohols [15], resins $[16,17]$ or sugars [18] require using in the process organic solvents. The electrochemical and economic properties of C/LFP material suggest the application in $x E V$ and ESS.

The $\mathrm{Li}_{2} \mathrm{MSiO}_{4}(\mathrm{M}=\mathrm{Fe}, \mathrm{Mn}, \mathrm{Co}, \mathrm{Ni})$ silicate systems as insertion materials for $\mathrm{Li}$-ion batteries were firstly proposed by prof. Goodenoug's group $[8,19]$. The materials crystallize in orthorhombic olivine structure $\left(\mathrm{Pmn} 2_{1}\right)$, similar to $\mathrm{LiFePO}_{4}$ system. The possibility of reversible exchange of two lithium ions per formula unit and in consequence exchange of two electrons by transition metal results in high theoretical capacity, up to $333 \mathrm{mAh} / \mathrm{g}$ for $\mathrm{Li}_{2} \mathrm{MnSiO}_{4}$ system. The calculation of electrochemical potential of lithium ions insertion/deinsertion shows a two-step reaction [20, 21]: for process $\mathrm{M}^{2+} / \mathrm{M}^{3+}$ from $3.2 \mathrm{~V}$ (Fe) to $4.1-4.4 \mathrm{~V}(\mathrm{Mn}, \mathrm{Co}, \mathrm{Ni})$ and for process $\mathrm{M}^{3+} / \mathrm{M}^{4+} 4.5-5.2 \mathrm{~V}(\mathrm{Mn}, \mathrm{Co}, \mathrm{Ni})$. The high potential of deinsertion of the second lithium ions limited by the liquid electrolytes properties which are stable only up to $4.8 \mathrm{~V}$. Low electrical conductivity $\left(\sim 10^{-12}-10^{-15} \mathrm{~S} / \mathrm{cm}\right.$ at room temperature) of $\mathrm{Li}_{2} \mathrm{MSiO}_{4}$ systems as well as observed diffusion limitation in the materials require application of the similar strategy than that for LFP material, i.e., preparation of carbon coated nanoparticles of active silicate material $[22,23]$. The presence of strong covalent bonds of $\mathrm{SiO}_{4}^{4-}$ tetrahedron in the structure results in high chemical and thermal stability what can greatly improve the safety of Li-ion batteries based on the silicate materials.

The improvement of Li-ion batteries performance depends on the development of new and more efficient electrode materials and the development of new manufacturing processes of nanomaterials of already commercially used systems. The use of nanomaterials as electrode materials in Li-ion batteries leads to achievement of the operating parameters close to the theoretical values and to increase cells power. The large surface area of nanomaterials significantly increases the charge transfer at the electrolyte-active material interface what increases current density in the cell. The lowering of active material particle sizes significantly shortens the diffusion paths of lithium ions what decreases the polarization of the electrode material.

The disadvantage of the usage of nanometric electrode materials is the increase in their reactivity towards electrolyte, surface reactivity in particular. This affects cells stability and safety. The solution to this problem may be the usage of protective coatings on nanomaterials with greater chemical stability (e.g. carbon) and the formation of nanocomposites wherein the coating must not limit the electrical conductivity of the system. Another limitation resulting from the use of nanomaterials is the agglomeration of nanoparticles during the preparation of standard composite (physical mixture) with carbon conductive additive used in Li-ion technology. In such composite, particle sizes of the carbon additive are comparable or larger than grain sizes of the active material. This affects the homogeneity of the system and decreases the efficient usage of total mass of the active material. The solution to the above limitations is the application of conductive carbon layers permeable for lithium ions and covering each of nanometric active material grains. This provides stable electrical connection of nanometric active material grains with current collector via three-dimensional network of nanometric carbon layers, improves the homogeneity of the nanocomposite, increases chemical stability of the material towards electrolyte and can decrease the amount of carbon additive.

\section{NANOCOMPOSITES WITH SELF-ASSEMBLED CONDUCTIVE CARBON LAYERS}

In the Li-ion batteries technology, the cathode composites are produced as physical mixture of the active material, carbon additive and polymeric binder. Such solution, as it was mentioned in the earlier text, results in low homogeneity of the composite in the case of usage of the active material in the form of nanomaterial of high surface 
reactivity. The conception of cathode nanocomposite is based on formation of nanometric conductive carbon layers (CCL) directly on the active material particles (Fig. 1).

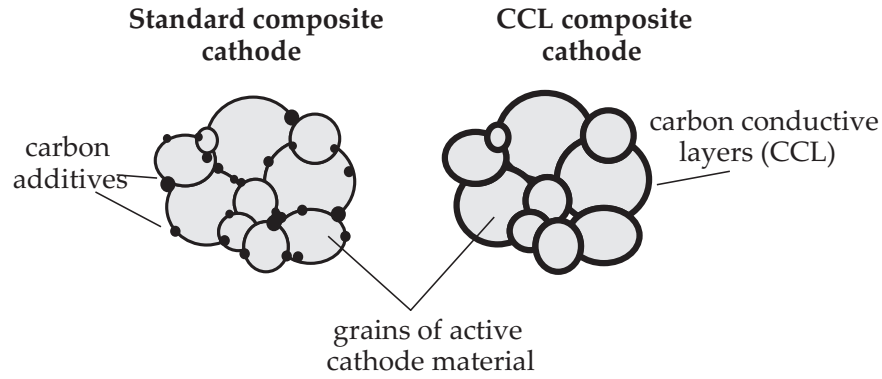

Fig. 1. Comparison of standard Li-ion composite with proposed CCL nanocomposite

In the developed process on assumed the aqueous deposition of polymer precursor and possibility to control of the morphology and electrical properties of carbon layers CCL. Then, deposited on the surface of the grains (active material) polymer precursor in a subsequent step was carefully carbonized $\left(400-800^{\circ} \mathrm{C}\right)$, wherein the active material has to remain unaltered. The developed technology concerns the technological process for the preparation of conductive carbon layer on powdered supports, it consists two main stages. First stage includes preparation of carbon precursor during free radical polymerization of hydrophilic polymer in water solution. The nanocoating precursor is a mixture of hydrophilic polymers with pyromellitic acid. The second stage covers the following processes: impregnation in suspension of active material by water solution of nanocoating precursor, water removal and composite precursor drying. Then the CCL nanocomposite is formed carbonization of carbon precursor under controlled conditions and nanocoating formation.

The optimization of the process conditions for producing CCL layers was conducted on a model $\alpha-\mathrm{Al}_{2} \mathrm{O}_{3}$ system [24-26]. As a carbon precursor, hydrophilic polymers soluble in water (good surface wettability): poly- $N$-vinylformamide (PNVF) and polyacrylamide (PAAm) were applied and the deposition was carried by impregnation method. The applied method combines the characteristics of coating techniques from liquid (solution) and solid phase. The course of the study was to demonstrate the key influence of the chemical properties of polymeric carbon precursor on the efficiency of composite preparation [27] and on properties of obtained pyrolytic carbons $[25,28]$. The further studies focused on optimization of the polymer precursor composition in order to optimize the electrical properties and the morphology of the conductive carbon layers. The breakthrough was the use of special polymer precursor composition (called MPNVF) containing pyromellitic acid (PMA) as a modifier of carbon layers structure [29-35].

The applied modifier (pyromellitic acid) plays the role of promoter which structuralizes and facilitates graphitization (improves nucleation of graphene domains) of polymer precursor and allows self-assembling of conductive carbon layers on the support. This improves electrical properties and morphology of CCL and at the same time reduces the pyrolysis temperature [26]. The specific role of PMA modifier is manifested by the fact that it is not a direct carbon precursor. The pyrolysis process of PMA resulted in its total decomposition. The improvement of the properties of CCL carbons was observed only in a narrow optimum range of PMA concentration in the polymer composition (approx. $5 \mathrm{wt} \%$ ). For this composition the best graphitization (Fig. 2a) and the best electrical conductivity (Fig. 2b) was achieved in CCL system [29].

The addition of PMA to the polymeric precursor composition substantially modified the morphology of the obtained CCL carbon layers [26]. The decrease of surface area and microporosity of the model CCL $/ \alpha-\mathrm{Al}_{2} \mathrm{O}_{3}$ nanocomposite obtained from MPNVF precursor in comparison to the PNVF precursor was observed. This effect should be beneficial for the formation of the intermediate solid electrolyte interphase (SEI) between the carbon layers of the CCL nanocomposite and a liquid electrolyte. Furthermore, the addition of PMA allows specific self-assembly of conductive carbon layers on the surface support and creation of a specific mesoporous structure with

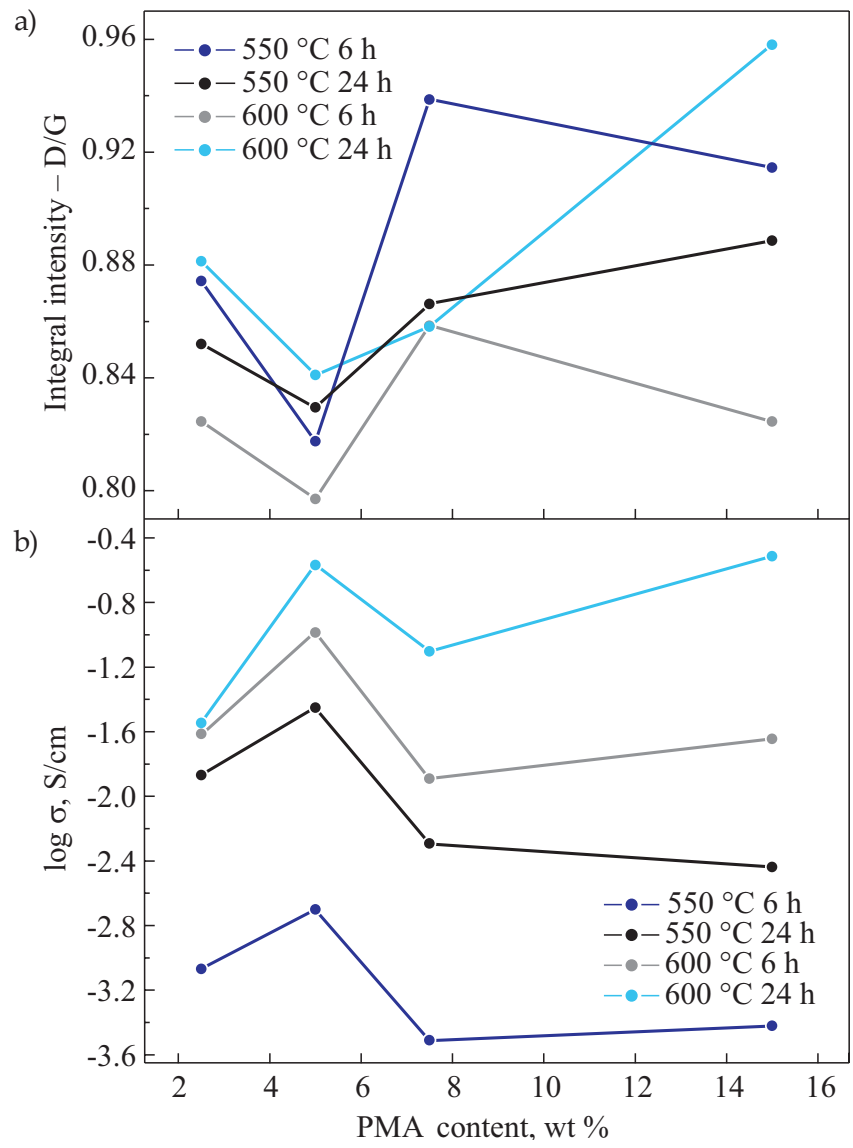

Fig. 2. a) Integral intensity ratio of D/G Raman bands of pyrolytic carbons derived from MPNVF with various PMA content, b) electrical conductivity of pyrolytic carbons derived from MPNVF with various PMA content [29] 


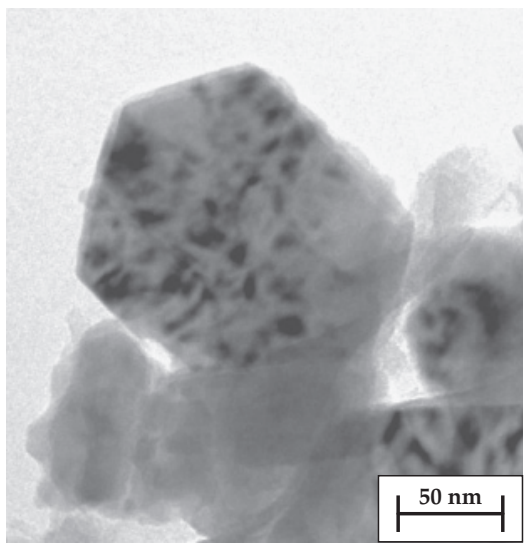

Fig. 3. HR-TEM images of model CCL/ $\alpha-\mathrm{Al}_{2} \mathrm{O}_{3}$ nanocomposite

a narrow pore size distribution of diameter in the range of $3.0-4.5 \mathrm{~nm}$. It was found that the morphology of the CCL carbon layers obtained in the developed process is reproducible and independent from the support type [26, 30]. Such morphology of the layers is particularly useful and necessary for easy transport (diffusion) of lithium ions through the carbon coating of cathode nanocomposite.

The high-resolution transmission electron microscopy (HR-TEM) images of model CCL $/ \alpha-\mathrm{Al}_{2} \mathrm{O}_{3}$ nanocomposite confirmed the efficiency of the developed method (Fig. 3).

The obtained nanocomposites revealed precise coverage of support grains by tight, close fitting amorphous carbon layers.

\section{SYNTHESIS AND CHARACTERIZATION OF $\mathrm{CCL} / \mathrm{LiFePO}_{4} \mathrm{CATHODE} \mathrm{NANOCOMPOSITE}$}

$\mathrm{CCL} / \mathrm{LiFePO}_{4}$ cathode nanocomposites were obtained from microcrystalline $\mathrm{LiFePO}_{4}$ (Pulead Technology Industry Co., Ltd.) by the developed method of CCL composites preparation. The structural studies performed on the nanocomposites confirmed that the process of coating with CCL layers was non-destructive for the LFP material. This confirmed the effectiveness of the proposed method.

The increase of electrical conductivity of CCL/LFP nanocomposites up to $10^{-2} \mathrm{~S} / \mathrm{cm}$ was observed (electrical conductivity of LFP is $10^{-9} \mathrm{~S} / \mathrm{cm}$ ). HR-TEM studies showed

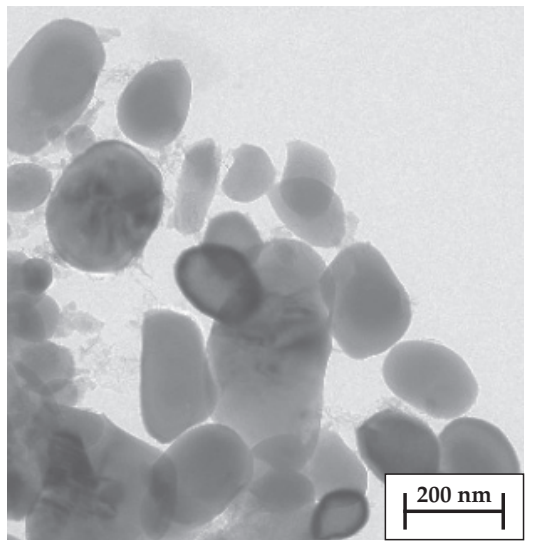

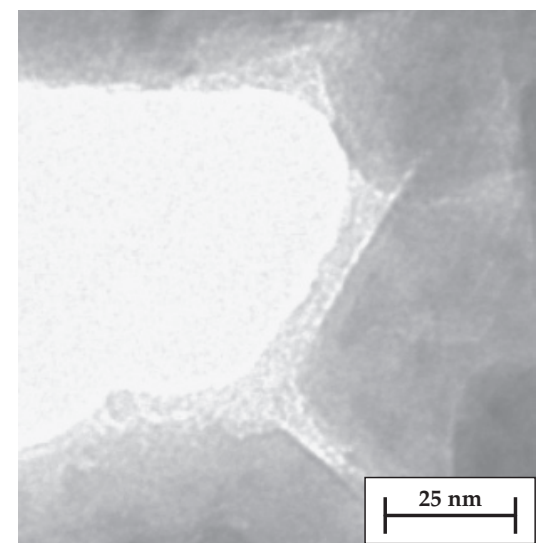

good coverage of LFP active material with amorphous conductive carbon layers of 3-4 nm thickness (Fig. 4).

The obtained cell voltage characteristics $\mathrm{Li} / \mathrm{Li}^{+} /(\mathrm{CCL} /$ $\mathrm{LiFePO}_{4}$ ) showed excellent reversibility of the electrochemical process and stability of CCL/LFP nanocomposites. The reversible capacity was $150 \mathrm{mAh} / \mathrm{g}$ after $10^{\text {th }} \mathrm{cy-}$ cles ( $\mathrm{C} / 5$ current rate) (Fig. 5).

It was found that in the initial cycles of battery work the activation of the nanocomposite occurred. The capacity of the cell increased while polarization of CCL/LFP cathode decreased. The most probably, this effect was related to the activation of the lithium diffusion channels (easy pathways) through the CCL carbon layers. Further research on the properties of CCL/nanoLFP nanocomposites [36] obtained from nanometric $\mathrm{LiFePO}_{4}$ active material confirmed this hypothesis. For CCL/nanoLFP nanocomposites reversible capacity of $165 \mathrm{mAh} / \mathrm{g}(\mathrm{C} / 5)$ was obtained and this was the value close to the theoretical capacity for LFP material. Similarly to nanocomposites prepared from microcrystalline LFP for CCL/nanoLFP nanocomposites result in the decrease of polarization of the cathode and the increase of the cell capacity was observed in subsequent cycles. Thus, the observed was not related to the active LFP material.

The developed preparation method of electrode nanocomposites with self-assembled conductive carbon layers allowed to produce high performance CCL/LFP

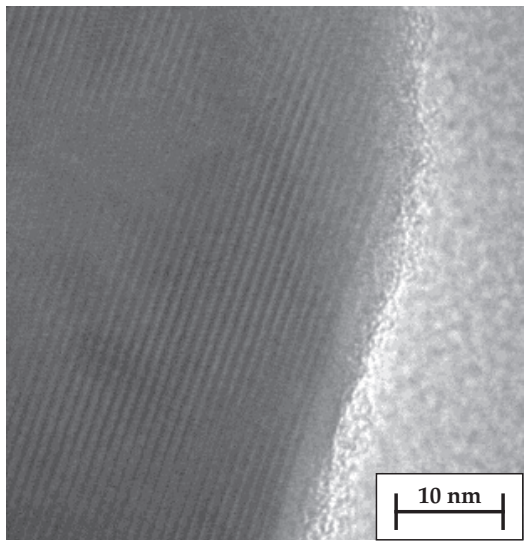

Fig. 4. HR-TEM images of $\mathrm{CCL} / \mathrm{LiFePO}_{4}(\mathrm{CCL} / \mathrm{LFP})$ nanocomposite 

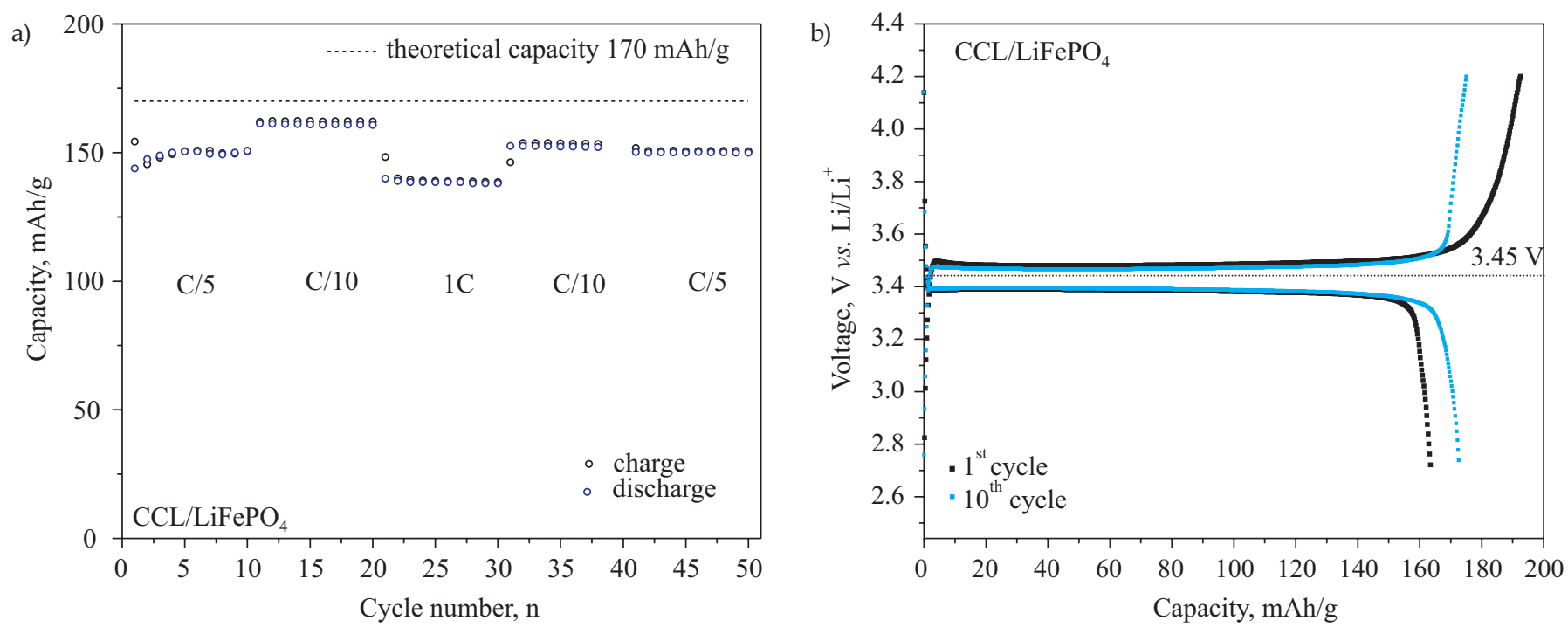

Fig. 5. Cell cycling behavior of $\mathrm{Li} / \mathrm{Li}^{+} /\left(\mathrm{CCL} / \mathrm{LiFePO}_{4}\right)$ : a) change in specific charge/discharge capacity as a function of cycle number at various $C$ rates (current rates), b) comparison between $1^{\text {st }}$ cycle and $10^{\text {th }}$ cycle of charge/discharge performance measured at $C / 5$ rate, in a voltage range of $2.7-4.2 \mathrm{~V}$

cathode nanocomposite and to verify the CCL nanocomposites model.

\section{THE DEVELOPMENT OF SYNTHESIS METHOD AND CHARACTERIZATION OF NANOSTRUCTURAL $\mathrm{Li}_{2} \mathrm{MnSiO}_{4}$ CATHODE MATERIAL AND CCL/Li $\mathrm{MnSiO}_{4}$ NANOCOMPOSITES}

Nanometric $\mathrm{Li}_{2} \mathrm{MnSiO}_{4}$ (LMS) cathode materials were obtained by the developed sol-gel method of Pechini type $[37,38]$. Optimization of synthesis process conditions allowed to obtain single-phase materials with nanometric grain size and average size of crystallites of 5-10 $\mathrm{nm}$. During the process the residual carbon matrix was formed from the organic precursor of sol-gel method. The residual carbon matrix prevented the growth of nanometric grains of the material. In the initial phase of the research it was supposed that residual carbon will be sufficient to produce $\mathrm{C} / \mathrm{Li}_{2} \mathrm{MnSiO}_{4}$ nanocomposites in a one-step process. However, despite the very high

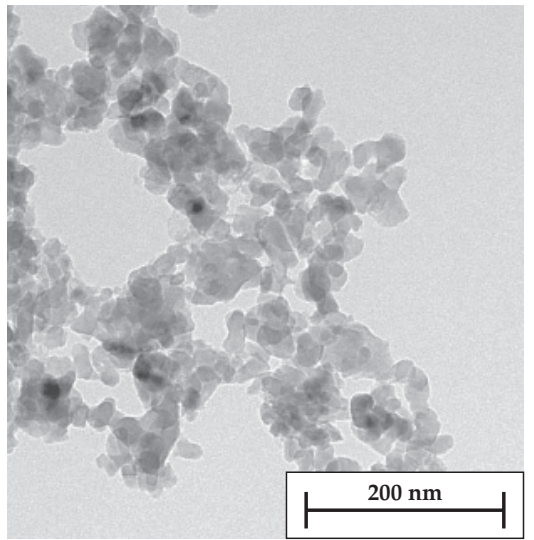

electrical conductivity (above $10^{-1} \mathrm{~S} / \mathrm{cm}$ ) of the obtained materials poor reversibility of electrochemical process and poor capacity of cells was observed [37]. This resulted from inadequate electrochemical properties and morphology of residual carbon matrix. The thermal stability study of $\mathrm{Li}_{2} \mathrm{MnSiO}_{4}$ material allowed to define process conditions for removing of residual carbon. At this stage, it was possible to apply the method of CCL nanocomposites preparation and to obtain CCL/LMS nanocomposites (Fig. 6).

The obtained cathode nanocomposite showed significant improvement in electrochemical properties. The reversible capacity was $100 \mathrm{mAh} / \mathrm{g}$, but a very low current rate $(C / 200)$ was applied. This indicated large diffusion limitations in the $\mathrm{Li}_{2} \mathrm{MnSiO}_{4}$ material and possible work within one electron range. The optimization of the properties of $\mathrm{CCL} / \mathrm{Li}_{2} \mathrm{MnSiO}_{4}$ nanocomposite resulted in the further improvement of observed electrochemical characteristics. The obtained capacity reached $318 \mathrm{mAh} / \mathrm{g}$ in the $1^{\text {st }}$ cycle and $160 \mathrm{mAh} / \mathrm{g}$ in the $10^{\text {th }}$ cycle under increased to C/50 current rate [39] (Fig. 7).

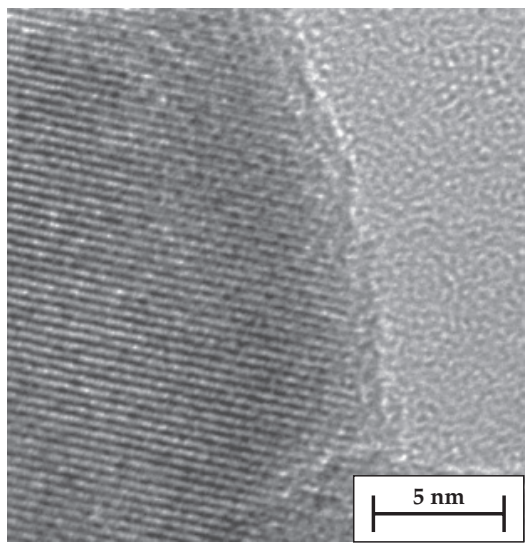

Fig. 6. HR-TEM images of $\mathrm{CCL} / \mathrm{Li}_{2} \mathrm{MnSiO}_{4}$ (CCL/LMS) nanocomposite 
a)

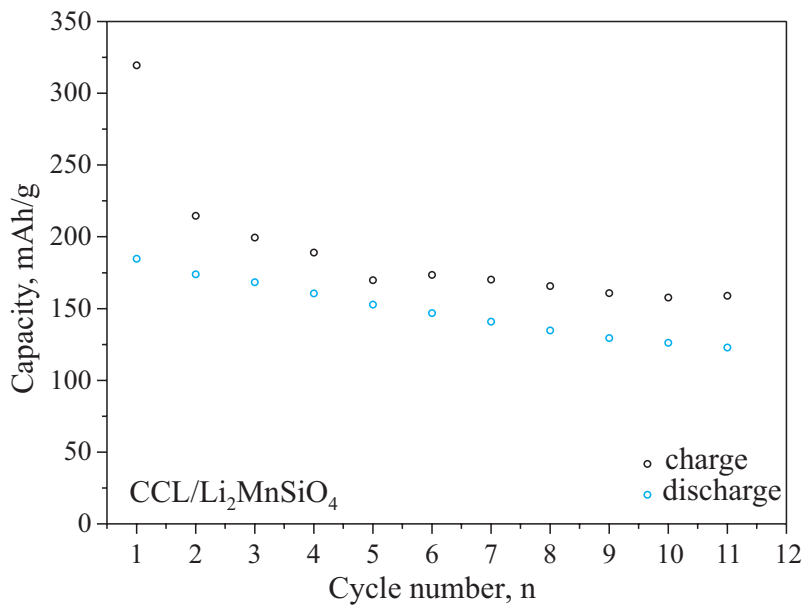

b)

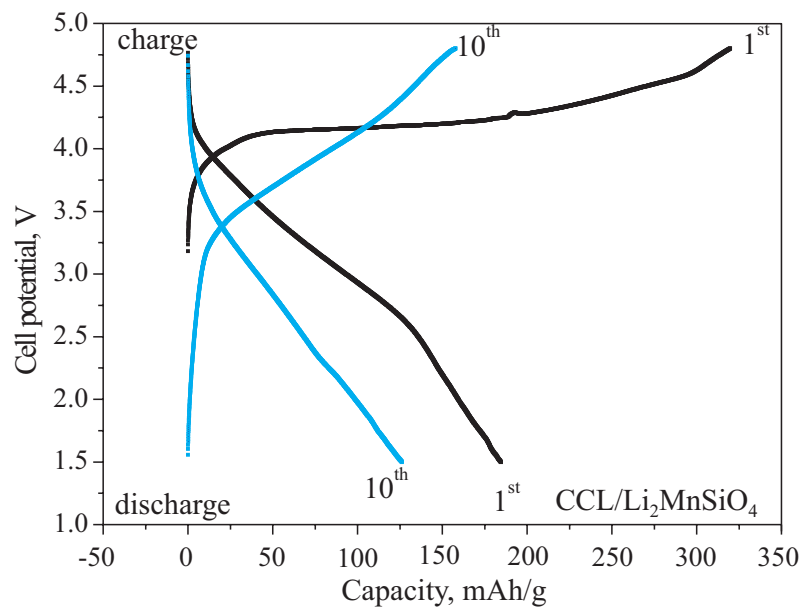

Fig. 7. Cell cycling behavior of $\mathrm{Li} / \mathrm{Li}^{+} /\left(\mathrm{CCL} / \mathrm{Li}_{2} \mathrm{MnSiO}_{4}\right)$ : a) change in specific charge/discharge capacity as a function of cycle number at $C / 50$ rate, $b$ ) comparison between $1^{\text {st }}$ and $10^{\text {th }}$ cycles of charge/discharge performance measured at $C / 50$ rate, in a voltage range of $1.5-4.8 \mathrm{~V}$

It was found that in the $1.5-4.8 \mathrm{~V}$ potential range of the cell the reversible exchange of only one lithium ion per formula unit of $\mathrm{Li}_{2} \mathrm{MnSiO}_{4}$. Moreover, the partial amorphization of the material during first cycle was found. The X-ray photoelectron spectroscopy (XPS) study of $\mathrm{CCL} / \mathrm{Li}_{2} \mathrm{MnSiO}_{4}$ nanocomposites in different states of charge (SOC) confirmed very good reversibility of insertion/deinsertion of one lithium ion and reversible changes in oxidation state of $\mathrm{Mn}^{2+} / \mathrm{Mn}^{3+}[40,41]$. For CCL/ $\mathrm{Li}_{2} \mathrm{MnSiO}_{4}$ the activation of the CCL carbon layers as well was observed. That occurred during the first cycle and was related to reordering towards more stable graphene domains assisted by the formation of intermediate SEI layer. The stability of the CCL layers towards $\mathrm{LiPF}_{6}$ electrolyte was confirmed [39]. Electrochemical impedance spectroscopy (EIS) study of CCL/ $\mathrm{Li}_{2} \mathrm{MnSiO}_{4}$ material at different SOC showed that the observed in the first cell cycle amorphization of $\mathrm{Li}_{2} \mathrm{MnSiO}_{4}$ increases its electronic conductivity and increases the diffusivity of lithium ions in the system [40].

The obtained results on nanostructural $\mathrm{Li}_{2} \mathrm{MnSiO}_{4}$ cathode material and $\mathrm{CCL} / \mathrm{Li}_{2} \mathrm{MnSiO}_{4}$ nanocomposites showed that the developed CCL method can be successfully applied to silicate-based cathode nanocomposites. The reversibility of the electrochemical process in the one electron range was achieved and the resulting capacities corresponded well to the theoretical capacity for one electron process.

\section{CONCLUSIONS}

The main trends in development of Li-ion battery technology presented above allowed to identify the current limitations and determinations of the research area and the scientific goal. The development of new nanostructured and nanocomposite electrode materials with self-assembled conductive carbon layers and the development of processes for their preparation to be used in technology of safe Li-ion batteries with improved parameters. A functional model of nanocomposites with self-assembled conductive carbon layers was shown in Fig. 8.

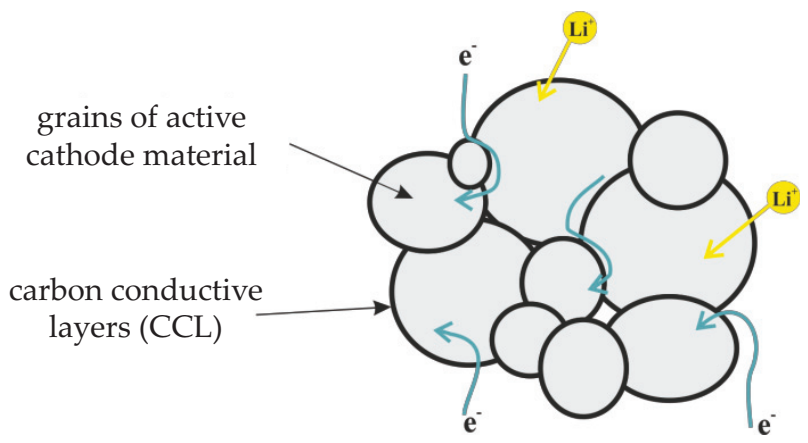

Fig. 8. Functional model of nanocomposite electrode

In such nanocomposites the physicochemical properties of CCL layers ensure total implementation of the following functions:

- increase the macroscopic electrical conductivity of the nanocomposite resulting from close coating of (nano)grains material with CCL layers forming a three-dimensional conductive network;

- ensure the easy diffusion paths (permeability) of lithium ions through the carbon layer (membrane) resulting from the unique mesoporous structure of CCL;

- increase the chemical stability of the active (nano)material surface towards electrolyte resulting from lowering of the contact area between active material and electrolyte solvent;

- absorb volume changes of the active (nano)material during the intercalation process thanks to the binary structure ( $s p^{2}$ and $s p^{3}$ hybridization of carbon atoms) of amorphous CCL.

This work is supported by National Science Centre, Poland under research grant No. 2014/13/B/ST5/04531. 


\section{REFERENCES}

[1] Bensalah N., Dawood H.: Journal of Material Science \& Engineering 2016, 5, 1000258.

http://dx.doi.org/10.4172/2169-0022.1000258

[2] Whittingham M.S.: Science 1976, 192, 1126.

http://dx.doi.org/10.1126/science.192.4244.1126

[3] Nagaura T., Tozawa K.: Progress in Batteries \& Solar Cells 1990, 9, 209.

[4] Tarascon J.-M., Guyomard D.: Electrochimical Acta 1993, 38, 1221.

https://dx.doi.org/10.1016/0013-4686(93)80053-3

[5] Tarascon J.-M., Armand M.: Nature 2001, 414, 359. http://dx.doi.org/10.1038/35104644

[6] Whittingham M.S.: Solid State Ionics 2000, 134, 169. http://dx.doi.org/10.1016/S0167-2738(00)00724-4

[7] Johnson C.S., Li N., Vaughey J.T. et al.: Electrochemistry Communications 2005, 7, 528.

http://dx.doi.org/10.1016/j.elecom.2005.02.027

[8] Amatucci G.G., Du Pasquier A., Blyr A. et al.: Electrochimica Acta 1999, 45, 255. http://dx.doi.org/10.1016/S0013-4686(99)00209-1

[9] Padhi A.K., Nanjundaswamy K.S., Goodenough J.B.: Journal of The Electrochemical Society 1997, 144, 1188. http://dx.doi.org/10.1149/1.1837571

[10] Goodenough J.B., Kim Y.: Chemistry of Materials 2010, 22, 587. http://dx.doi.org/10.1021/cm901452z

[11] Armand M., Tarascon J.-M.: Nature 2008, 451, 652. http://dx.doi.org/10.1038/451652a

[12] Kim J.K., Cheruvally G., Ahn J.-H.: Journal of Solid State Electrochemistry 2008, 12, 799. http://dx.doi.org/10.1007/s10008-007-0425-y

[13] Fey G.T.K., Lu T.L., Wu F.Y., Li W.H.: Journal of Solid State Electrochemistry 2008, 12, 825. http://dx.doi.org/10.1007/s10008-008-0516-4

[14] Lin B., Wen Z., Han J., Wu X.: Solid State Ionics 2008, 179, 1750. http://dx.doi.org/10.1016/j.ssi.2007.12.054

[15] Guo R., Shi P., Cheng X., Du Ch.: Journal of Alloys and Compounds 2009, 473, 53.

http://dx.doi.org/10.1016/j.jallcom.2008.05.102

[16] Cushing B.L., Goodenough J.B.: Solid State Sciences 2002, 4, 1487. http://dx.doi.org/10.1016/S1293-2558(02)00044-4

[17] Hassoun J., Derrien G., Panero S., Scrosati B.: Journal of Power Sources 2008, 183, 339. http://dx.doi.org/10.1016/j.jpowsour.2008.05.017

[18] Kim J.K., Cheruvally G., Ahn J.-H., Ahn H.-J.: Journal of Physics and Chemistry of Solids 2008, 69, 1257. http://dx.doi.org/10.1016/j.jpcs.2007.10.047

[19] Padhi A.K., Nanjundaswamy K.S., Masquelier C. et al.: Journal of The Electrochemical Society 1997, 144, 1609. http://dx.doi.org/10.1149/1.1837649

[20] Arroyo-de Dompablo M.E., Armand M., Tarascon J.-M., Amador U.: Electrochemistry Communications 2006, 8, 1292. http://dx.doi.org/10.1016/j.elecom.2006.06.003

[21] Gong Z.L., Li Y.X., Yang Y.: Journal of Power Sources 2007, 174, 524.

http://dx.doi.org/10.1016/j.jpowsour.2007.06.250

[22] Nyten A., Abouimrane A., Armand M. et al.: Electrochemistry Communications 2005, 7, 156.

http://dx.doi.org/10.1016/j.elecom.2004.11.008

[23] Kokalj A., Dominko R., Mali G. et al.: Chemistry of Materials 2007, 19, 3633.

http://dx.doi.org/10.1021/cm0630111

[24] Molenda M., Dziembaj R., Piwowarska Z., Drozdek M.: Journal of Thermal Analysis and Calorimetry 2007, 88, 503. http://dx.doi.org/10.1007/s10973-006-8226-6

[25] Molenda M., Dziembaj R., Drozdek M. et al.: Solid State Ionics 2008, 179, 197.

http://dx.doi.org/10.1016/j.ssi.2007.12.034

[26] Molenda M., Świętosławski M., Drozdek M. et al.: Journal of Nanomaterials 2014, 2014, 103418. http://dx.doi.org/10.1155/2014/103418

[27] Molenda M., Dziembaj R., Podstawka E. et al.: Journal of Power Sources 2007, 174, 613. http://dx.doi.org/10.1016/j.jpowsour.2007.06.117

[28] Molenda M., Dziembaj R., Piwowarska Z., Drozdek M.: Solid State Ionics 2008, 179, 88. http://dx.doi.org/10.1016/j.ssi.2007.12.033

[29] Molenda M., Chojnacka A., Natkański P. et al.: Journal of Thermal Analysis and Calorimetry 2013, 133, 329. http://dx.doi.org/10.1007/s10973-013-3212-2

[30] Molenda M.: Functional Materials Letters 2011, 4, 129. http://dx.doi.org/10.1142/S1793604711001713

[31] PL Pat. 216549 B1 (2014).

[32] US Pat. 8846135 B2 (2014).

[33] JP Pat. 5476383 B2 (2014).

[34] KR Pat. 10-2011-7 004142 (2015).

[35] EP Pat. 2326745 A2 (2017).

[36] Świder J., Molenda M., Kulka A., Molenda J.: Functional Materials Letters 2016, 9, 1641007. http://dx.doi.org/10.1142/S1793604716410071

[37] Molenda M., Świętosławski M., Rafalska-Łasocha A., Dziembaj R.: Functional Materials Letters 2011, 4, 135. http://dx.doi.org/10.1142/S1793604711001749

[38] Molenda M., Świętosławski M., Dziembaj R.: “Composites and Their Properties", (Ed. Hu N.), InTech, Croatia 2012, pp. 61-80.

[39] Świętosławski M., Molenda M., Furczoń K., Dziembaj R.: Journal of Power Sources 2013, 244, 510. http://dx.doi.org/10.1016/j.jpowsour.2013.02.078

[40] Molenda M., Świętosławski M., Wach A. et al.: Solid State Ionics 2014, 262, 98.

http://dx.doi.org/10.1016/j.ssi.2013.11.007

[41] Świętosławski M., Molenda M., Grabowska M. et al.: Solid State Ionics 2014, 263, 99. http://dx.doi.org/10.1016/j.ssi.2014.05.005

Received 28 III 2017. 